\title{
KREDITRENDSZERU゙ KÉPZÉSEK MINTATANTERVEINEK ÉS ELŐTANULMÁNYI HÁLÓINAK ELEMZÉSE A HAZAI MATEMATIKA ALAPSZAKOK PÉLDÁJÁN
}

\author{
BERGMANN JÚLIA, MOLONTAY ROLAND, \\ SZABÓ MIHÁLY, SZEKRÉNYES DÓRA LAURA
}

\begin{abstract}
Dolgozatunkban egyrészt a kreditrendszerű képzések előtanulmányi hálóinak jellemzésére és összehasonlíthatóságára mutatunk néhány módszert, majd ezeket a magyarországi matematika alapképzéseken szemléltetjük. Áttekintjük a tantervi hálók elemzésének irodalmát, illetve bemutatunk egy teljesítési adatokra alapuló valószínüségi modellt is. Ezen módszerek segítségével olyan kérdésekre kaphatunk választ, hogy egy adott tantervben melyek a legfontosabb, leghangsúlyosabb tantárgyak, illetve az elötanulmányi háló topológiája hogyan hat a képzés várható teljesítési idejére. Másrészt ismertetünk néhány felvételi statisztikát az elmúlt évekből, többek között a matematika alapszakokra felvett hallgatók létszámára, illetve felvételi pontszámaira vonatkozóan.
\end{abstract}

\section{Bevezetés}

"Életünk legszebb évei", így emlékezünk vissza az egyetemi évekre, ugyanakkor a diákok izgatottan várják felsőfokú tanulmányaik befejezését és a diploma megszerzését. A diploma megszerzéséig vezető utat a képzések mintatanterve, elötanulmányi rendje jelöli ki. Ebben a cikkben egyetemi képzések előtanulmányi hálóját elemezzük gráfelméleti és valószínűségszámítási eszközökkel. Az előtanulmányi rend egy irányított gráffal írható le, ahol a csúcsok a tantárgyaknak felelnek meg, és irányított él fut két csúcs között, ha az egyik tantárgy előkövetelménye a másiknak.

Az oktatásszervezési kérdések kvantitatív módszereken alapuló és adatvezérelt támogatására egyre nagyobb figyelem irányul úgy az oktatási kormányzat és a felsőoktatási intézmények vezetői részéről, mint a kutatók részéről itthon és külföldön egyaránt $[4,9,11,12,18]$.

Az elmúlt években több cikk is született előtanulmányi hálózatok elemzéséról, melyről jó áttekintést ad Wigdahl munkája [27]. Slim és szerzőtársai felismerték, 
hogy a hallgatók egyetemi előrehaladásában az előtanulmányi rend nagy szerepet játszik, ők a mintatantervek elemzésére a komplex hálózatok elméletéből és a gráfelméletből ismert módszereket használják [21].

Ugyanezen szerzők elemzik a mintatantervek hatékonyságát és tanulmányi elömentelre vonatkozó hatásukat gráfelméleti módszerekkel [28]. Az előtanulmányi rendből kiindulva lineáris regresszió és Markov-hálózatok segítségével prediktív analitikai elemzést végeznek a hallgatók teljesítményére vonatkozóan [20], továbbá hálózatelméleti eszközökkel vizsgálják a kurzusok ${ }^{1}$ előtanulmányi rendben betöltött szerepét az Új-mexikói Egyetem képzésein [21]. Szintén hálózatelméleti módszertannal vizsgálja a mintatanterveket Aldrich [2] és Lightfoot [17].

Több tanulmány született a mintatantervek egyszerủ és hatékony vizualizációját, illetve az előtanulmányi rendben való eligazodást, a kurzusfelvétel megkönnyítését segítő rendszerek tervezésével kapcsolatban is $[1,3,15]$.

A mintatantervek és előtanulmányi hálók vizsgálatának másik megközelítési módja a hallgatói folyamok modellezése. Számos tanulmányban vizsgálták hallgatói áramokat szimulálva, hogy a mintatantervek átszervezésének milyen hatása lenne a hallgatók elörehaladására vonatkozóan [19, 23, 26]. A mintatanterv hallgatói teljesítményre vonatkozó hatását vizsgálta Jansen és van der Hulst is [14, 25], a hallgatói folyamok modellezésekor figyelembe véve a tanulók korát, nemét, tanulmányi átlagát és a középiskolás eredményeit. Rahim és szerzőtársai Markovlánc alapú modellezést használnak posztgraduális képzések hallgatói áramainak elemzésére [24]. A hallgatók előrehaladásának és végzési rátájának jobb nyomonkövethetősége érdekében a hallgatók áramlását vizualizálták Sankey-diagramok segítségével friss cikkükben Horváth és szerzőtársai [13].

\section{Mintatantervi gráfok elemzése}

Ebben a fejezetben ismertetjük a mintatantervek elemzéséhez általunk használt matematikai eszközöket. A továbbiakban feltételezzük, hogy az olvasó tisztában van az alapvető gráfelméleti és valószínüségszámítási fogalmakkal. ${ }^{2}$

\subsection{Mintatantervi gráf}

A kreditrendszerű képzésben a tantárgyak felvételének feltétele, hogy az adott tantárgy (általában korábbi félév(ek)ben szereplő) előzetes követelményeit (döntően másik tantárgya(ka)t) a hallgató már teljesítse. A kreditrendszerű mintatanterv ábrázolásának legszemléletesebb módja az ún. előtanulmányi háló. A képzések előtanulmányi rendje természetes módon jellemezhető gráfokkal, pontosabban irányí-

\footnotetext{
${ }^{1}$ Dolgozatunkban a tantárgy és kurzus megnevezéseket szinonimaként használjuk.

${ }^{2}$ Ha mégsem lenne így, $[5,16]$ forrásokat ajánljuk.
} 
tott körmentes gráfokkal (DAG). A gráf csúcsai a tantárgyaknak felelnek meg, az irányított élek pedig az előkövetelményi rendszert jelölik. Jelölje $M_{i, j} n \times n$-es mátrix a gráf szomszédossági mátrixát, ahol $n$ a vizsgált kurzusok száma, és $M_{i, j}=1$ pontosan akkor, ha az $i$ kurzus előfeltétele $j$ kurzusnak, vagyis $j$ tantárgy nem vehetö fel $i$ sikeres teljesítése nélkül. Ez a megközelítés nem veszi figyelembe az ún. gyenge előkövetelmény lehetőségét. További egyszerüsítő feltételezéseinkről a 4. és 5. fejezetekben írunk bővebben.

Egy tantárgy fontossága, képzésben betöltött szerepe nagyon sokféleképpen definiálható, és számos tényezőtől függhet. Mi a következőkben ezt a „fontosságot" az előtanulmányi hálóban betöltött szerepek alapján kvantifikáljuk. Mérőszámokat mutatunk mind az egyes tantárgyakra, mind az előtanulmányi háló egészének struktúrájára, sürüségére vonatkozóan. Először az előtanulmányi háló topológiájából származtatott mutatókat ismertetjük, később bevezetünk néhány új, valószínüségi alapokon nyugvó mérőszámot.

\subsection{Topológikus mutatók}

\section{Késleltetési tényező (delay factor)[22]}

A késleltetési tényező megmutatja, hogy egy kurzus sikertelen teljesítése biztosan maga után vonja-e a képzési idő megnövekedését. A késleltetési tényező értéke legyen a reciproka annak a számnak, ahányadszori bukás már biztosan félévvesztést okoz a képzés elvégzését illetően. Tehát egy adott kurzus késleltetési faktora 1, ha a kurzus nem teljesítése egy félévnyi csúszással jár, és $1 / 3$, ha kétszer „büntetlenül” bukhatunk, de a harmadik nem teljesítés már biztosan félévvesztést okoz. A fogalmat az 1. ábrán látható két rövid, három féléves mintatanterv segítségével szemléltetjük. Vegyük észre, hogy míg a Mintatanterv 1 esetén az A tantárgy sikertelen teljesítése után még mindig pozitív valószínüséggel végezhető el a program időben, azaz három félév alatt (feltételezve, hogy minden tantárgy meghirdetésre kerül minden félévben), addig a második képzésen a B tantárgy kivételével minden sikertelenség automatikus csúszást eredményez. Ilyen esetekben mondhatjuk, hogy $A, C$ és $D$ jobban késleltetnek, mint $B$, hiszen $\mathrm{A}, \mathrm{C}$ és D tantárgy késleltetési tényezője 1 , B tantárgyé pedig $1 / 2$. 

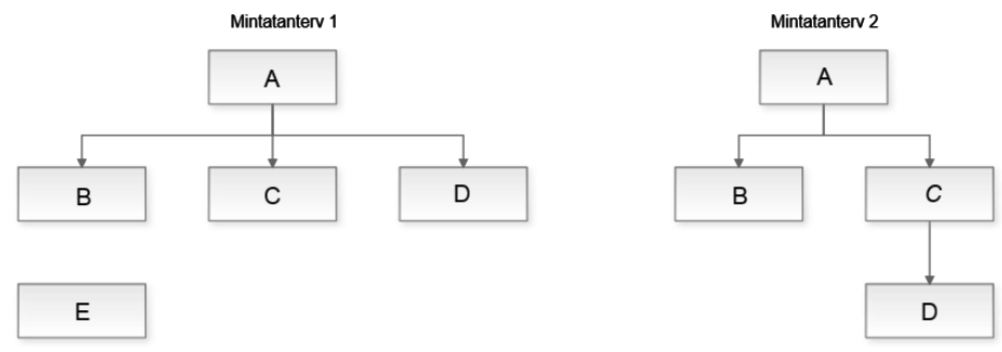

1. ábra. Késleltetési tényező.

\section{Blokkoló tényezö (blocking factor)[22]}

Természetes gondolat, hogy egy tantárgy minél több kurzusnak előkövetelménye, annál fontosabb a képzésen. Formálisan azt mondhatjuk, hogy egy kurzus blokkoló tényezőjének értéke $n \in \mathbb{N}$, ha pontosan $n$ darab leszármazottja van a gráfban, azaz a csúcsból pontosan $n$ másik csúcsba vezet irányított út. Vizsgáljuk a 2. ábrán feltüntetett mintatanterveket. Vegyük észre, hogy az A tantárgy különböző fontossággal bír a két mintatanterv esetén. Az első esetben csak egy, míg a másodikban két tantárgynak is előkövetelménye, tehát utóbbiban fontosabbnak számít.
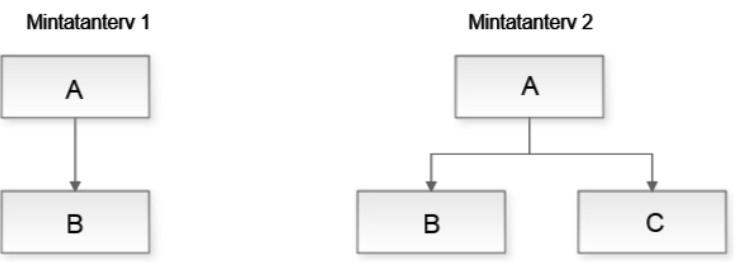

2. ábra. Blokkoló tényező

\section{Keveredés (dissimilar mixing)[22]}

A kurzusokat számos szempont szerint csoportosíthatjuk, például témaköre vagy a tantárgyat oktató tanszék szerint. Ezen csoportosítás ismeretében vizsgálhatjuk, hogy az egyes tantárgycsoportok mekkora mértékben építenek más csoportok kurzusaira, azaz mennyi él fut egy csoportba a többiből. A gráf irányítottságából adódóan ez a mérőszám nem szimmetrikus. A keveredés mértékének 
meghatározására vezessük be a következő mennyiséget:

$$
e_{r s}=\frac{1}{m} \sum_{i, j} M_{i j} \delta\left(c_{i}, r\right) \delta\left(c_{j}, s\right),
$$

ahol $r$ és $s$ tantárgytípusok (tanszékek), $c_{i}$ jelöli az $i$ tantárgy típusát, $m$ az élek száma és $\delta$ a Kronecker-delta függvény. Azt mondhatjuk, hogy minél nagyobb az $e_{r s}$ érték, annál szorosabban kapcsolódnak az $s$ típusú tantárgyak az $r$ típusú tantárgyakhoz.

\section{Kölcsönös központiság (betweenness centrality)[17]}

Az ún. kölcsönös központiság segít megtalálnunk a gráf különböző részei között gócpontokat formáló csúcsokat. Egy $v$ csúcs (azaz esetünkben kurzus) kölcsönös központiságán a következőt értjük:

$$
b_{v}=\sum_{s \neq v, t \neq v} \frac{\sigma_{s t}(v)}{\sigma_{s t}},
$$

ahol $\sigma_{s t}$ az összes $s$-böl $t$-be menő legrövidebb utak száma, $\sigma_{s t}(v)$ pedig azon ilyen utak, amelyek áthaladnak $v$ csúcson. Irányított gráf lévén irányított utakról beszélünk.

A kölcsönös központiság szofisztikált mérték, és különböző módosításait a hálózatelméletben széleskörben alkalmazzák [6], [8]. Az előtanulmányi hálók ugyanakkor speciális gráfok, a DAG-tulajdonságuk miatt a fenti mérték kevésbé jól használható fontosságot rendel a kurzusokhoz. A kölcsönös központiság minden első féléves tantárgyhoz triviálisan 0-t fog rendelni, függetlenül attól, hány másik tantárgynak előkövetelménye.

\section{Összefüggő komponensek (connected components)[2]}

Az összefüggő komponens olyan tovább nem bővíthető részgráf, melynek bármely két csúcsát út köti össze. A mintatantervek irányított gráfok, a továbbiakban a gyengén összefüggö komponenseket tekintjük (ezek az irányítatlan gráfban összefüggő komponensek). Mintatantervi gráfoknál az ilyen komponensek egy-egy elkülönített tudományterületet jelölnek. Érdekes kérdés, hogy a különböző témák hogyan kapcsolódnak egymáshoz, mennyire építenek egymásra, ezt hivatott mérni a már említett keveredés.

\section{Utak (paths)[28]}

Egy mintatantervi gráfban a leghosszabb út az előkövetelmények leghosszabb láncát jelöli. A hosszú utak olyan kurzusokat tartalmaznak, amik nagy hatással lehetnek a végzési időre. Ezen csúcsok késleltetési faktora tipikusan magas (azaz 1 
vagy ahhoz közeli), hiszen ezek azok, amelyek sikertelen teljesítése könnyen okozhat csúszást a hallgató életében. Egy hatféléves képzés esetén egy 4-hosszú út, ami 5 csúcsból és 4 élből áll, már hosszúnak tekinthető.

\section{Üvegnyakak (bottlenecks)[28]}

Vizsgálva az egyes csúcsok ki- és befokát (jelölés: $\Delta^{+}(v), \Delta^{-}(v)$ ), előfordulhatnak kiemelkedően sok szomszéddal rendelkező kurzusok. Egy $i$ kurzusra akkor mondjuk, hogy üvegnyak, ha $\Delta^{+}(v)>a$, vagy $\Delta^{-}(v)>a$, vagy $\Delta^{+}(v)+\Delta^{-}(v)>b$ valamilyen $a, b \in \mathbf{N}$ rögzített konstansra. Formálisan, egy programban pontosan

$$
b_{n}(G)=\sum_{v \in V(G)} \mathbb{1}\left[\left(\Delta^{+}(v)>a\right) \vee\left(\Delta^{-}(v)>a\right) \vee\left(\Delta^{+}(v)+\Delta^{-}(v)>b\right)\right],
$$

darab üvegnyak van, ahol $a$ és $b$ értékét a képzés hosszától és a gráf sürüségétől függően határozzuk meg. Ezen kurzusok sikertelen teljesítése könnyen félévvesztést eredményezhet.

\subsection{Sztochasztikus mutatók}

Az előbbi mérőszámok hiányossága, hogy csupán a gráf topológiáján alapszanak, és nem veszik figyelembe a csúcsok áteresztő képességét, azaz, hogy a kurzusok elvégzési valószínüsége között nagy különbségek lehetnek. Az alábbiakban bevezetünk olyan új mérőszámokat, melyek az előbbi problémákat hivatottak áthidalni.

\section{Várható végzési idő}

Egy tantervet az jellemez legjobban, hogy mennyi idő alatt lehet (várhatóan) elvégezni. Ezt alapvetően két dolog határozza meg: az előtanulmányi háló struktúrája és az egyes tantárgyak elvégzési valószínüségei. Az alábbiakban a gráfot a - modellünk szerinti - végzési idejével, mint valószínüségi változóval, és annak várható értékével jellemezzük. Célunk, hogy meghatározzuk a végzési idő $(X)$ valószínüségi változójának súlyfüggvényét:

$$
p(x)=\mathbb{P}(X=x) .
$$

Ennek alapján a várható végzési idő könnyen kiszámítható:

$$
\mathbb{E}(X)=\sum_{x} x \cdot p(x) .
$$

\section{Áteresztő hatás}

A várható végzési idő tárgyalása után természetesen adódik a kérdés, hogy az egyes tantárgyak milyen hatással vannak a végzési időre. A kérdés megválaszolásához az alábbi egyszerüsített modellt tekintjük. Legyen adott egy virtuális reprezentatív hallgató, aki az előtanulmányi rend szerint igyekszik haladni 
tanulmányaival, és az $i$-edik tantárgyat $p_{i}$ valószínüséggel végzi el (függetlenül a múlttól). Egy tantárgy elvégzését csak akkor kísérelheti meg, ha az összes előkövetelményét már sikeresen teljesítette, illetve a tantárgy mintatanterv szerinti féléve nem előzi meg az aktuális félévet. A modellünk reprezentatív hallgatója az aktuális félévben az összes olyan tantárgy elvégzését megkísérli, amit a mintatanterv és az elötanulmányi rend megenged számára.

Ebben a modellben a reprezentatív hallgató várható végzési ideje a tantárgyak teljesítési valószínüségeitől, illetve a mintatanterv topológiájától függ. Tételezzük fel, hogy ez az $\mathbb{E}(X)=f\left(p_{1}, \ldots, p_{n}\right)$ függvénnyel írható fel.

A függvényformát ismerve meghatározhatjuk, hogy az egyes tantárgyak teljesítési valószínüségeiben fellépő kis változás milyen hatással van a képzés várható teljesítési idejére, azaz tekinthetjük a következő parciális deriváltat:

$$
d_{i}=\frac{\partial f\left(p_{1}, \ldots, p_{n}\right)}{\partial p_{i}}
$$

Hasonlóan érdekes érték a képzés teljesítésének kurzusok elvégzési ideje szerinti rugalmassága (elaszticitása):

$$
d_{i}^{e}=\frac{\partial \log f\left(p_{1}, \ldots, p_{n}\right)}{\partial \log p_{i}} .
$$

A reprezentatív hallgató tantárgyteljesítési valószínüségeit valós historikus adatokból a következőképpen tudjuk becsülni:

$$
p_{i}=\mathbb{P}(\text { az } i \text { kurzus sikeres teljesítése }) \approx \frac{\text { sikeresen teljesítő hallgatók száma }}{\text { kurzust felvett hallgatók száma }} \text {. }
$$

A 3. fejezetben még részletesebben visszatérünk a fent ismertetett valószínüségi modellre, az áteresztő hatásra és annak kiszámítására.

\section{Végzési idők kiszámítása}

A tantervek végzési idejének kiszámítása bár látszólag egyszerü és könnyen érthető, gyorsan meglehetősen bonyolulttá válik. Egy nagyon rövid mintatanterven fogjuk bemutatni a problémát (3. ábra).

Modellünkben egy tantárgy első felvételétől számított, félévekben mért elvégzési idejét egy $p$ paraméterű (optimista ${ }^{3}$ ) geometrai valószínüségi változó adja meg. Ez azt jelenti, hogy ebben a megközelítésben egy tantárgy többedszeri felvétele nem változtatja annak elvégzési valószínüségét. Továbbá feltesszük, hogy az egyes tantárgyak végzési idejei is függetlenek egymástól.

\footnotetext{
${ }^{3}$ matematikai értelemben
} 


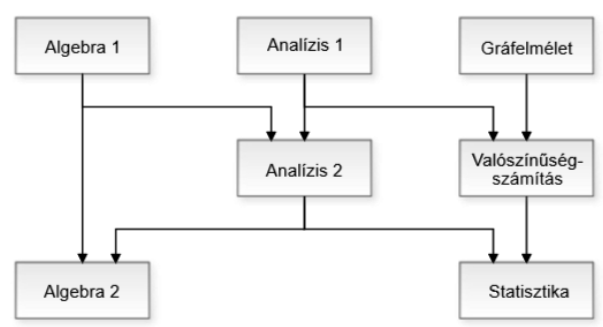

3. ábra. Egy képzeletbeli mintatanterv.

\begin{tabular}{l|c|c}
\hline Tantárgy & Valószínűségi változó & Eloszlás \\
\hline Algebra 1 & $X_{1}$ & $\sim \operatorname{Geom}\left(p_{1}\right)$ \\
Analízis 1 & $X_{2}$ & $\sim \operatorname{Geom}\left(p_{2}\right)$ \\
Gráfelmélet & $X_{3}$ & $\sim \operatorname{Geom}\left(p_{3}\right)$ \\
Analízis 2 & $Y_{1}$ & $\sim \operatorname{Geom}\left(q_{1}\right)$ \\
Valószínúségszámítás & $Y_{2}$ & $\sim \operatorname{Geom}\left(q_{2}\right)$ \\
Algebra 2 & $Z_{1}$ & $\sim \operatorname{Geom}\left(r_{1}\right)$ \\
Statisztika & $Z_{2}$ & $\sim \operatorname{Geom}\left(r_{2}\right)$ \\
\hline
\end{tabular}

1. táblázat. A képzeletbeli mintatanterv tárgyai.

Ebben az esetben könnyű megállapítani, hogy az első féléves kurzusok elvégzésének várható ideje rendre $\frac{1}{p_{1}}, \frac{1}{p_{2}}$ és $\frac{1}{p_{3}}$. Tekintsük most az Analízis 2 c. kurzust! Ennek előkövetelménye az Algebra 1 és az Analízis 1. Könnyen látszik, hogy ekkor az Analízis 2 beiratkozástól számított elvégzési ideje a következő valószínüségi változóval írható le: $\max \left\{X_{1}, X_{2}\right\}+Y_{1}$. Ezt továbbgondolva, minden tantárgyhoz felírhatjuk a tantárgy beiratkozásától számított elvégzési idejét, amit a 2.táblázatban foglaltunk össze. A fenti valószínüségi változók súlyfüggvényé-

\begin{tabular}{l|c}
\hline Tantárgy & Elvégzési idő valószínüségi változója \\
\hline Algebra 1 & $X_{1}$ \\
Analízis 1 & $X_{2}$ \\
Gráfelmélet & $X_{3}$ \\
Analízis 2 & $\max \left\{X_{1}, X_{2}\right\}+Y_{1}$ \\
Valószínüségszámítás & $\max \left\{X_{2}, X_{3}\right\}+Y_{2}$ \\
Algebra 2 & $\max \left\{X_{1}, \max \left\{X_{1}, X_{2}\right\}+Y_{1}\right\}+Z_{1}$ \\
Statisztika & $\max \left\{\max \left\{X_{1}, X_{2}\right\}+Y_{1}, \max \left\{X_{2}, X_{3}\right\}+Y_{2}\right\}+Z_{2}$ \\
\hline
\end{tabular}

2. táblázat. A képzeletbeli mintatanterv kurzusaihoz tartozó valószínüségi változók. 
nek és várható értékének analitikus meghatározása még kis mintatanterv esetén is problémás. Általánosan igaz, hogy az $X_{1}, \ldots X_{n}$ független $p$ paraméterű geometriai változók maximumának várható értéke $\sum_{k=0}^{\infty}\left(1-\left(1-q^{k}\right)^{n}\right)$, ahol $q=1-p$ [10]. Különböző valószínüségeket feltéve ez az érték $\sum_{k=0}^{\infty}\left(1-\prod_{i=1}^{n}\left(1-q_{i}^{k}\right)\right)$. Továbblépve a harmadik félévre, még nehezebb probléma elé kerülünk, hiszen itt már nem azonos eloszlású valószínűségi változók maximumának várható értékét keressük. Az analitikus megközelítés helyett ezért inkább Monte Carlo-szimulációval érdemes dolgozni [7].

\section{Egy elötanulmányi hálózat vizsgálata}

Az előző fejezetben ismertettünk néhány szempontot, ami jó alapul szolgál ahhoz, hogy egy egyetemi elötanulmányi gráfot vizsgáljunk. Ebben a fejezetben az Eötvös Loránd Tudományegyetem (továbbiakban: ELTE) matematika BSc képzését fogjuk közelebbről szemügyre venni.

A 4. ábra mutatja az ELTE matematika BSc képzés elméleti specializációjának előtanulmányi gráfját. Néhány egyszerüsítő feltétellel éltünk a vizsgálat során a könnyebb kezelhetőség és jobb átláthatóság érdekében. Csak a képzés kötelező kurzusait vizsgáltuk, a kötelezően, illetve a szabadon választható tantárgyakat elhagytuk, emellett nem vettük figyelembe az egyetem úgynevezett vagy-vagy elökövetelményi rendszerét. Ez utóbbi azt jelenti, hogy némely tantárgynak nincs egyértelmű előkövetelménye, hanem két különböző kurzus bármelyikének teljesítése esetén felveheti a hallgató az adott tantárgyat. A következő elemzésben kijelöltünk egy lehetséges utat, amivel teljesíthető a képzés, az ábrán kékkel jelöljük azon tantárgyakat, amelyek helyett más is választható lenne, pirossal azokat, amelyek vagy-vagy előkövetelményüek.

Már első ránézésre is látszik, hogy az előtanulmányi háló elég sűrü, azaz sok az előkövetelményi kapcsolat a tantárgyak között. Láthatjuk, hogy nincsenek nagy különálló összefüggő komponensek, és izolált pontból is viszonylag kevés van. A két leginkább üvegnyak szerepet betöltő tárgynak az Algebra 2 és az Analízis 2 címü kurzusok bizonyulnak, befokuk rendre 2 és 1, míg mindkét tantárgy kifoka 6. Számos hosszú út található a gráfban, sőt, van az egész képzést végigkísérö öt hosszú út is: Analízis 1 - Analízis 2 - Analízis 3 - Analízis 4 - Valószínűségszámítás 2 - Matematikai statisztika. Tehát ha ezen tantárgyak bármelyikét sikertelenül végzi egy hallgató, az feltétlen megnöveli a képzés teljesítéséhez szükséges félévek számát.

A csúcsokat vizsgálva a kölcsönös központiság szempontjából a legmagasabb értékeket a 3. táblázatban látjuk. 


\begin{tabular}{l|c}
\hline Kurzus & Kölcsönös központiság \\
\hline Algebra 2 & 1,00 \\
Analízis 3 & 0,64 \\
Analízis 2 & 0,54 \\
\hline
\end{tabular}

3. táblázat. Az ELTE legnagyobb kölcsönös központiságú kurzusai.

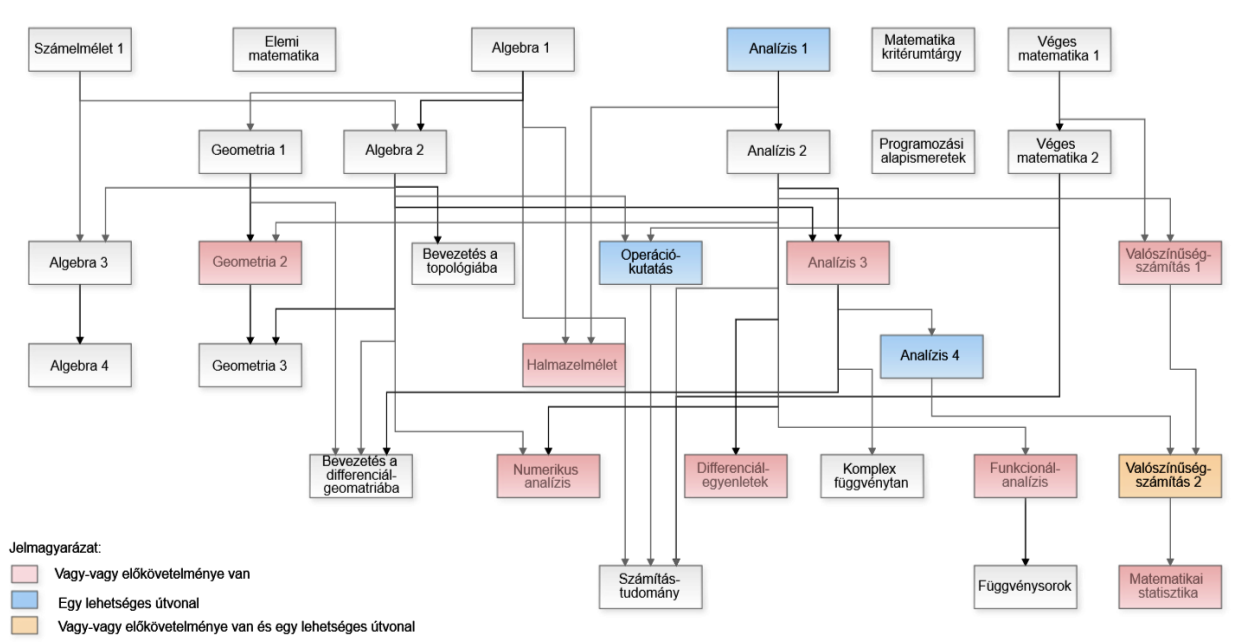

4. ábra. Az ELTE elméleti matematika specializáció képzésének mintatantervi gráfja.

A leghosszabb útra, valamint a ki- és befokokra tett megállapításainkat összegezve kijelenthetjük, hogy kizárólag az előtanulmányi háló struktúráját vizsgálva az Algebra 2, az Analízis 3 és az Analízis 2 kurzusok számítanak a legfontosabb tantárgyaknak ezen a képzésen.

A tantárgyak áteresztő hatását tekintve - valós teljesítési arányok hiányában - az összes tantárgynál azonos, 0,8-as teljesítési arányt feltételezve, szimulációnk alapján a következő tantárgyak teljesítési arányának (ceteris paribus) növelése csökkenti leginkább a képzés várható elvégzési idejét: Analízis $3(0,15)$, Analízis 4 $(0,14)$, Valószínűségszámítás $2(0,14)$. A zárójelbe írt szám azt jelenti, hogy ha az adott tantárgy teljesítési valószínűségét 0,8-ról 0,9-re növeljük (ceteris paribus), akkor a képzés félévekben mért várható elvégzési ideje a zárójelbe írt számértékkel csökken a 10000 reprezentatív hallgatóra futtatott szimuláció alapján. Felhívjuk a figyelmet, hogy ezeknek a tantárgyaknak a késleltetési tényezője is magas (1 értékü). 
Pontosabb képet akkor kaphatnánk, ha a kurzusok valós teljesítési arányait ismerve végeznénk el az elemzést.

Megvizsgáljuk az egyes tanszékek képzésen betöltött szerepét, súlyát három különböző megközelítésből. Az 5(a) ábra mutatja, hogy összesen az egyes tanszékeknek mennyi kötelezó órájuk van, míg az 5(b) ábrán az oktatott kreditek száma látszik. Az 5(c) ábra szemlélteti az oktatott órák átlagos kreditértékét.

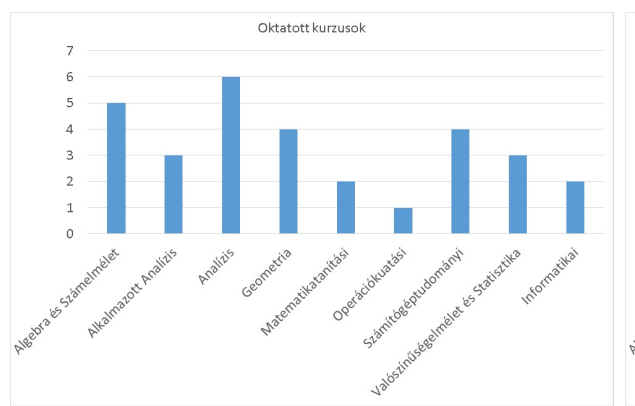

(a) kurzusok Átlagkredit

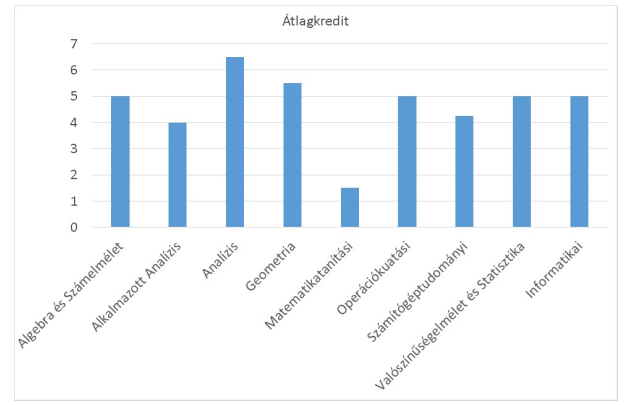

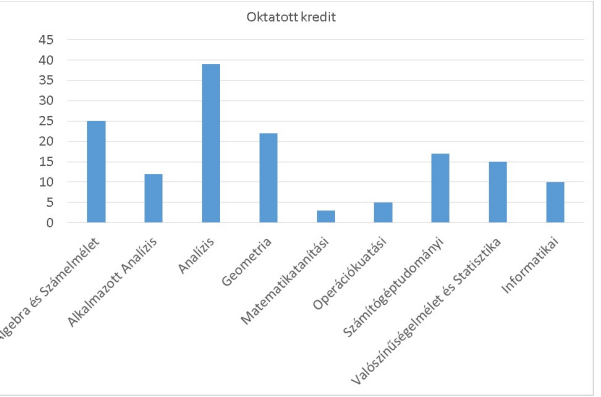

(b) összkredit

A megjelenített tantszékek balról jobbra:

1. Algebra és Számelmélet Tanszék

2. Alkalmazott Analízis és Számításmatematikai Tanszék

3. Analízis Tanszék

4. Geometria Tanszék

5. Matematikatanítási és Módszertani Központ

6. Operációkutatási Tanszék

7. Számítógéptudományi Tanszék

8. Valószínűségelméleti és Statisztikai Tanszék

9. Informatikai Kar

(c) kreditérték

5. ábra. Tanszékek megoszlása oktatott kurzusok száma (a), összkreditek száma (b), illetve átlagos kreditérték (c) alapján.

Az előző fejezetben definiáltuk az ún. keveredést, amely megállapítja a tanszékek közti kapcsolatot abban az értelemben, hogy melyik tanszék tantárgyai mennyire építenek előkövetelményként a másik tanszék tantárgyaira. Ezt a 6 . ábra szemlélteti, a tengelyeken a nyolc tanszék és egy "külsős" kar szerepel, a metszéspontokban lévő körök mérete azzal arányos, hogy a vízszintes tanszék tantárgyai hány esetben előkövetelményei a függőleges tanszéknek. (Tulajdonképpen ez a korábban említett $e_{r s}$ érték a normálástól eltekintve.)

Megjegyezzük, hogy a Matematikatanítási és Módszertani Központhoz tartozó sor, illetve oszlop ürességének oka a központ által oktatott tantárgyak (Elemi matematika és Matematika kritériumtárgy) izoláltsága az előtanulmányi hálóban (4. ábra). 


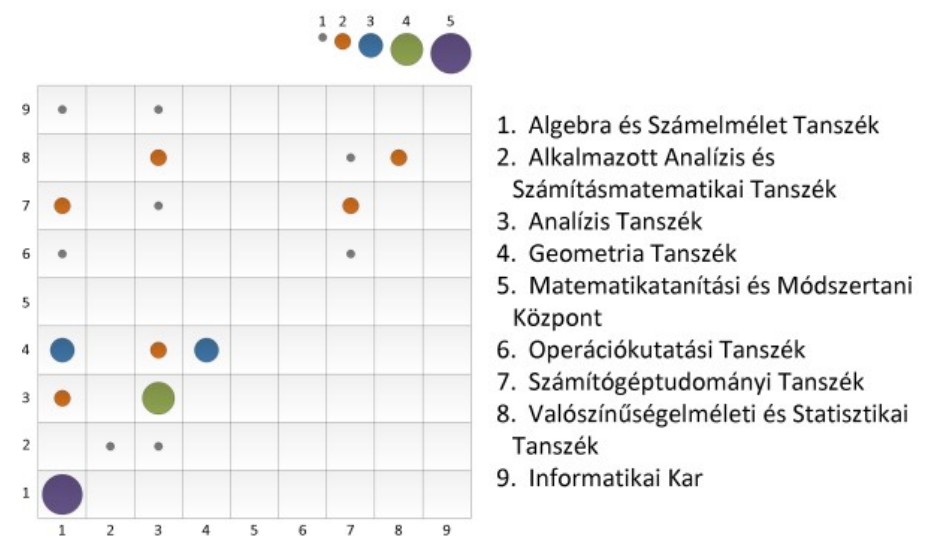

6. ábra. Tanszékek kapcsolata.

\section{Hazai matematika alapszakok tanterveinek összehasonlítása}

Ebben a fejezetben a Magyarországon akkreditált matematika alapképzések tantervét és előtanulmányi hálóját hasonlítjuk össze különböző szempontok alapján. A Budapesti Müszaki és Gazdaságtudományi Egyetem (BME), az Eötvös Loránd Tudományegyetem (ELTE), a Debreceni Egyetem (DE), a Pécsi Tudományegyetem (PTE) és az Eszterházy Károly Egyetem (EKE) matematika alapszakjait vizsgáljuk. A Szegedi Tudományegyetem (SZTE) nyilvánosan elérhető mintatanterv hiányában nem került az általunk elemzett egyetemek közé. Az elemzéseink során elsősorban a képzések elméleti specializációjára összpontosítottunk a könnyebb összehasonlíthatóság érdekében. A képzések nyújtotta további specializációs lehetőségekről a 7 függelékben lesz bővebben szó. Továbbra is csak a kötelező tantárgyakat vizsgáljuk, eltekintünk a vagy-vagy kapcsolatoktól, helyette egy lehetséges utat vizsgálunk, nem teszünk különbséget gyenge és erôs előkövetelmények ${ }^{4}$ között, és nem tekintjük külön kurzusnak az adott tantárgyból az előadást és a gyakorlatot.

\subsection{Elötanulmányi gráfok}

Ebben a részben szemléltetjük az egyes képzések gráfjait. Az ELTE előtanulmányi hálóját már korábban a 4 . ábrán bemutattuk.

\footnotetext{
${ }^{4}$ Gyenge előkövetelmény, ha csupán a gyakorlat vagy labor teljesítése elég a továbbhaladáshoz az előadás sikeres teljesítésétől függetlenül, illetve ha egyazon félévben végezhető az előkövetelmény és a ráépülő tantárgy.
} 


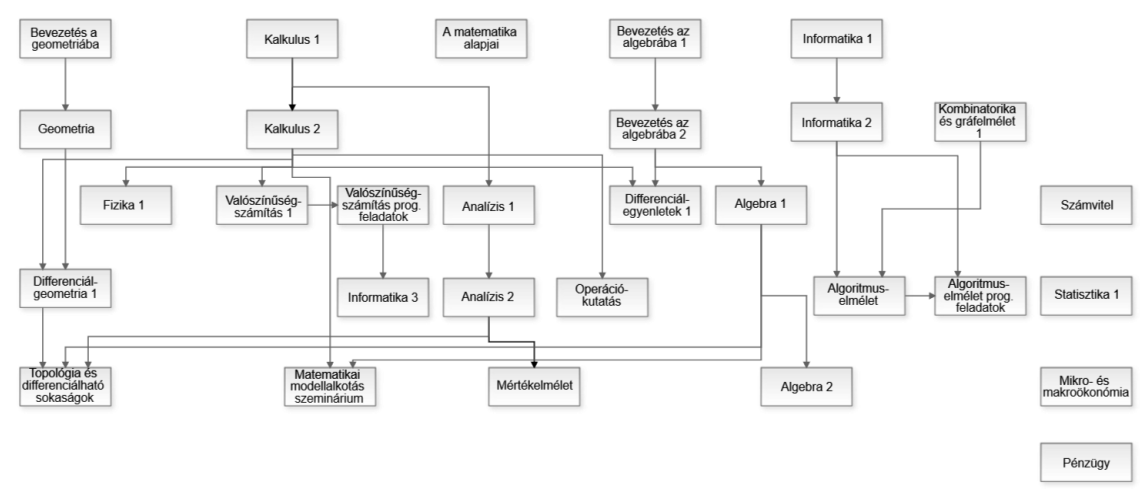

7. ábra. A BME elméleti matematika specializáció képzésének mintatantervi gráfja.

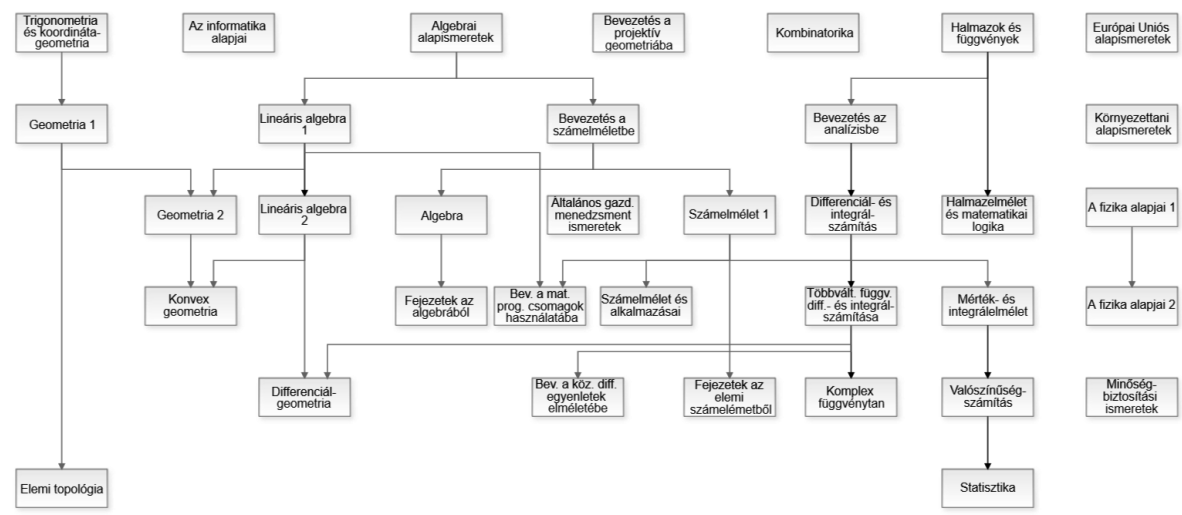

8. ábra. A DE elméleti matematika specializáció képzésének mintatantervi gráfja.

\subsection{A végzés várható ideje}

Mind a hallgatók, mind az egyetemek vezetősége érdekeltek abban, hogy megbecsüljék, a diákok várhatóan mikor szereznek diplomát. Ennek elméleti hátterét a 2. fejezetben, gyakorlati megvalósításának módját pedig a 3. fejezetben tárgyaltuk. Szimulációnkat 10000 virtuális reprezentatív hallgatóra végeztük. Valós statisztikai adatok hiánya miatt magunk választunk valószínüségeket a kurzusokhoz, jelen vizsgálatban minden tantárgy sikeres teljesítésének valószínüsége 0,8 . 


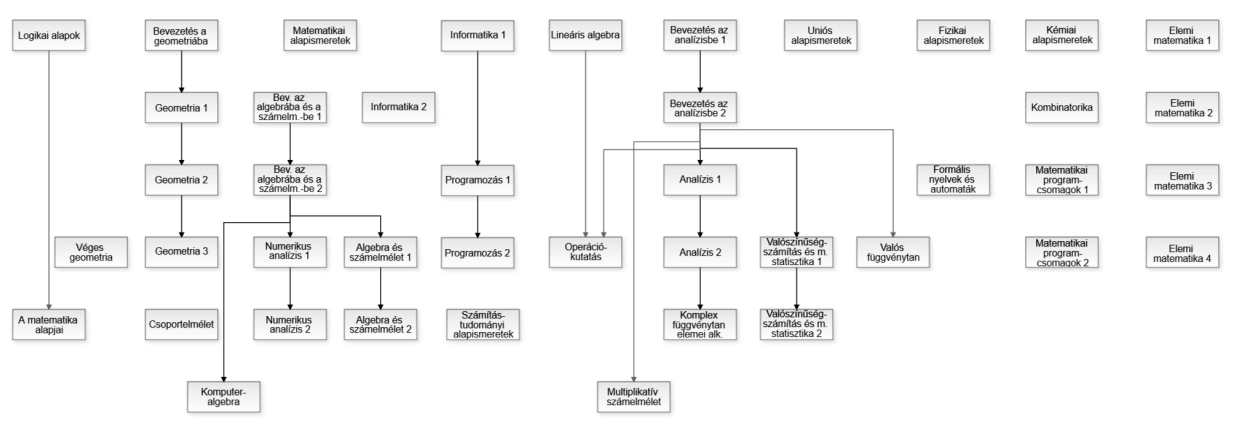

9. ábra. A PTE elméleti matematika specializáció képzésének mintatantervi gráfja.

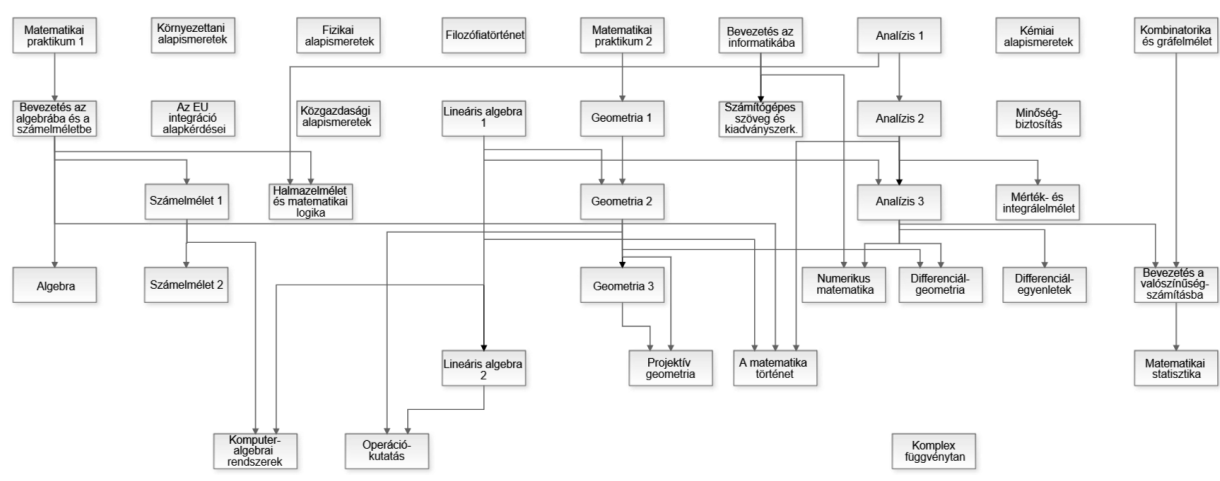

10. ábra. Az EKE elméleti matematika specializáció képzésének mintatantervi gráfja.

Amennyiben historikus adatokból a tényleges becsült valószínűségek rendelkezésre állnak, a módszer sokkal pontosabb eredményre vezet. További egyszerüsítő feltételünk, hogy minden tantárgy minden félévben indul, a különbözö tantárgyak teljesítései függetlenek egymástól, a hallgatóknak nincs passzív félévük, a hallgatók hamarabb nem veszik fel a tantárgyat, mint ahogy a tantervben szerepel, illetve nem teszünk különbséget az egyes hallgatók képességei között.

A következő ábrákon a hallgatók végzési idejének a modell által szimulált eloszlása látható a vizsgált egyetemek előtanulmányi hálói alapján, ahol a piros vonal az átlagos végzési időt jelöli. A függőleges tengely mutatja a végzett diákok arányát, továbbá a vízszintes tengelyen látható, hogy hányadik szemeszterben abszolváltak a szimulált hallgatók. Tehát, ha a 10 . félévben a végzettek aránya 0,3 , az azt jelenti, hogy 10000 szimulált hallgatóból 3 000-en fejezték be a tanulmányaikat a 10. félévben. A 10000 virtuális hallgató végzésének átlagos időpontját a piros vonal jelöli. 


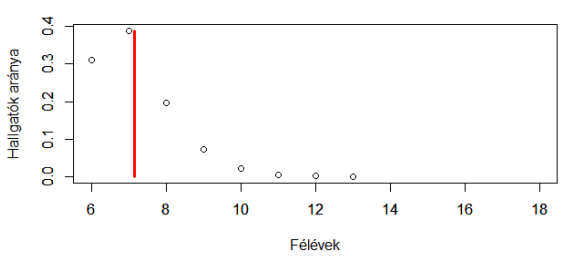

(a) BME

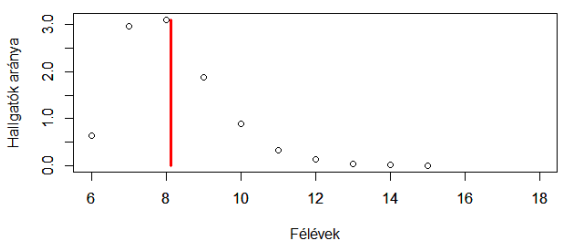

(c) ELTE

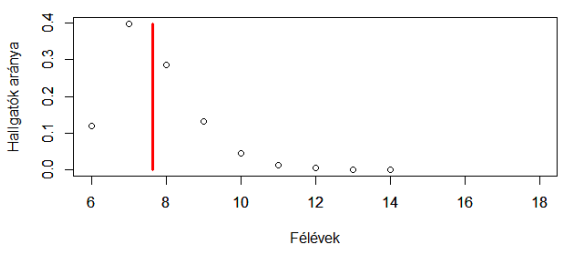

(e) EKE

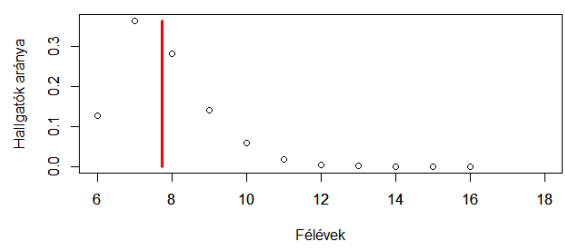

(b) DE

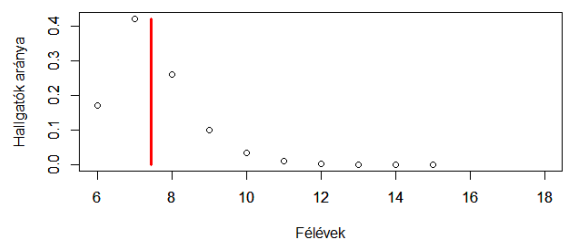

(d) PTE

11. ábra. A hallgatók végzési idejének szimulációval kapott eloszlása az egyes elméleti matematika specializáció képzéseken.

A fentiek alapján azt mondhatjuk, hogy az Eötvös Loránd Tudományegyetem képzésének a legsürübb az elötanulmányi rendje, mivel várhatóan itt szerzik meg legkésőbb a hallgatók az abszolutóriumukat. A szimulációnk szerint leggyorsabban a BME képzésén végeznek a hallgatók. Ez indokolható azzal, hogy a BME-n az alapképzés utolsó évében az elméleti specializáció hallgatói nagy szabadsággal rendelkeznek a tantárgyak összeállításával kapcsolatban. Fontos ismét hangsúlyozni, hogy ezek az eredmények a gráf topológiája alapján egyenlő teljesítési valószínüségekkel születtek. A valós teljesítési valószínüségek nagy mértékben megváltoztathatják ezeket az értékeket. 


\begin{tabular}{r|cccc}
\hline & Átlag & Szórás & Standard hiba & CI $(95)$ \\
\hline ELTE & 8,1308 & 1,3334 & 0,0133 & $(8,105 ; 8,157)$ \\
BME & 7,1222 & 1,0823 & 0,0108 & $(7,101 ; 7,143)$ \\
DE & 7,7348 & 1,2371 & 0,0124 & $(7,711 ; 7,759)$ \\
PTE & 7,4698 & 1,1259 & 0,0113 & $(7,448 ; 7,492)$ \\
EKE & 7,6487 & 1,1403 & 0,0114 & $(7,626 ; 7,670)$ \\
\hline
\end{tabular}

4. táblázat. A várható végzési idők átlaga, szórása, standard hibája és 95\%-os konfidenciaintervalluma.

\subsection{Keresztfélévben is induló tantárgyak feltételének elhagyása}

A keresztféléves kurzusok elindítása részben függ attól, hogy az milyen jelentőséggel bír a hallgatók végzési idejére vonatkozóan. Az 5. táblázat azon szimuláció eredményét mutatja képzésenként, amikor minden kurzust évente egyszer indítottunk, tavaszi vagy őszi félévben, azaz a keresztfélév lehetősége nélkül. Jól látszik, hogy keresztféléves tantárgyindítások hiányában jelentősen megnő a képzés elvégzésének ideje.

\begin{tabular}{r|cccc}
\hline & Átlag & Szórás & Standard hiba & CI $(95)$ \\
\hline ELTE & 11,3372 & 2,55 & 0,0255 & $(11,287 ; 11,387)$ \\
BME & 10,2765 & 2,3846 & 0,0238 & $(10,230 ; 10,323)$ \\
DE & 10,4996 & 2,3572 & 0,0236 & $(10,454 ; 10,546)$ \\
PTE & 10,4013 & 2,2738 & 0,0227 & $(10,357 ; 10,446)$ \\
EKE & 10,4224 & 2,396 & 0,0240 & $(10,376 ; 10,469)$ \\
\hline
\end{tabular}

5. táblázat. A várható végzési idők átlaga, szórása, standard hibája és 95\%-os konfidenciaintervalluma keresztfélév nélkül.

Az 5. táblázat alapján átlagosan a diákok több mint 10 félév alatt végeznek az alapszakon. Természetesen valós adatok esetén ezek az eredmények is módosulnak.

\subsection{További mutatók}

A várható végzési időn kívül a többi ismertetett mérőszám alapján is összehasonlítjuk a hazai matematika alapképzéseket. Ezen mutatók kizárólag az előtanulmányi hálók topológiáján alapszanak.

Megvizsgálva az öt mintatanterv leghosszabb útjait, azt kapjuk, hogy a BME-n csupán három lépés hosszú a leghosszabb út (6. táblázat), igaz ilyen hosszú utakból 


\begin{tabular}{r|cc}
\hline Egyetem & Leghosszabb út hossza & Leghosszabb utak száma \\
\hline BME & 3 & 10 \\
DE & 5 & 1 \\
EKE & 4 & 2 \\
ELTE & 5 & 1 \\
PTE & 4 & 1 \\
\hline
\end{tabular}

6. táblázat. Leghosszabb utak.

tíz különböző (de nem diszjunkt) út is van. A többi egyetemen a leghosszabb út négy vagy öt hosszú (azaz némelyik a teljes képzésen átível).

\begin{tabular}{r|cc}
\hline Egyetem & $\begin{array}{c}\text { Legalább kételemü összefüggö } \\
\text { komponensek száma }\end{array}$ & Izolált pontok száma \\
\hline BME & 1 & 4 \\
DE & 2 & 8 \\
EKE & 1 & 8 \\
ELTE & 1 & 3 \\
PTE & 5 & 15 \\
\hline
\end{tabular}

7. táblázat. Összefüggő komponensek.

A Pécsi Tudományegyetem és a Debreceni Egyetem kivételével mindegyik hazai matematika alapszak gráfja egy legalább kételemü komponensre épül, sőt, Debrecenben is csak egy kételemű csoport adja a többkomponensűséget (7. táblázat). Pécsett öt darabra hullik szét az előtanulmányi háló: logika, geometria, algebra és analízis, számelmélet, illetve informatika blokkokra. Ez a feldaraboltság segítheti a képzés elvégzését. Talán nem annyira meglepő eredmény, hogy korábbi megfigyelésünk alapján a PTE képzése büszkélkedhet a második legrövidebb várható végzési idővel (4. táblázat).

Térjünk át a csúcsokra vonatkozó topológiai mérőszámokra. A számszerủ eredmények táblázatai a Függelékben találhatók. Összességében elmondható, hogy minden képzésen kiemelten fontosnak számítanak az analízis, illetve az algebra tudományterületekhez köthető kurzusok a késleltetési tényező alapján. Hasonló mintázat látszódik az üvegnyak szerepet betöltő tantárgyak meghatározásakor. A kölcsönös központiságra vonatkozóan szintúgy ezen két tudományterület a kiemelendő, hiszen az ELTÉ-n egy algebra tárgy kapta a legnagyobb értéket (Algebra 2), míg a többi egyetemen az analízis témakörébe tartozó kurzusok nyertek (BME: Kalkulus 2, DE: Differenciál- és integrálszámítás, EKE: Analízis 3, PTE: Bevezetés az analízisbe 2). Ezen eredmények összecsengenek azon életből vett tapasztalata- 
inkkal is, miszerint az analízishez és az algebrához kötödő kurzusok okozzák a legnagyobb fejfájást a hallgatók jelentős részének.

\subsection{További lehetőségek}

Elemzésünk további adatok esetén bővíthető azzal, hogy tantárgyanként vizsgáljuk meg a keresztfélévben meghirdetett kurzusok hatását. Továbbá ezzel a modellezési keretrendszerrel vizsgálható az a kérdés is, hogy milyen hatása van többszöri sikertelen tantárgyteljesítésnek mint elbocsátási kritériumnak a végzettek arányára.

\section{Felvételi statisztikák}

Ebben a fejezetben a nappali tagozatos matematika alapképzések (a képzések részletes leírását lásd a Függelékben) felvételi statisztikáit elemezzük az elmúlt néhány évre vonatkozóan. Vizsgáljuk a felvett hallgatók számát, az önköltséges és államilag támogatott hallgatók arányát, a felvételi ponthatárokat és a felvettek átlagpontszámát. Most itt csak néhány ábrát közlünk, további ábrák, a forrásául szolgáló táblázatok, illetve egyéb elemzések megtalálhatóak a Függelékben.

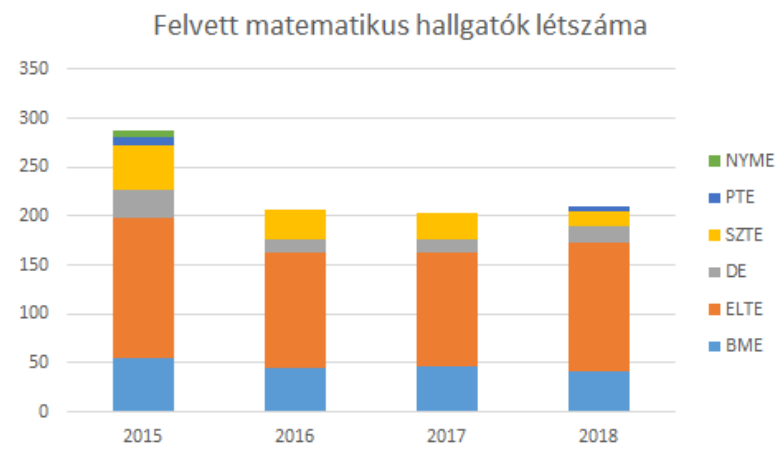

12. ábra. 2015 és 2018 között a felvételt nyert matematika BSc-s hallgatók létszáma egyetemenként.

A 12. ábrán megfigyelhető, hogy évről évre egyre kevesebb a matematika BSc szakra felvettek létszáma, bár 2018-ban ez a trend megfordulni látszik. Itt említjük meg, hogy 2017 óta a BME angol nyelven is elindítja a matematika alapszakot, amin félévente tíz-húsz fö körüli Stipendium Hungaricum ösztöndíjas hallgató kezdi meg tanulmányait. Az angol nyelvü képzés azonban nem képezi jelen vizsgálódásunk tárgyát. 
Fontos mérőszám a felvételi ponthatár. Az érettségizők mindig nagy figyelmet fordítanak az általuk megjelölt intézmény felvételi pontszámaira. A felvi.hu adatai alapján hasonlítottuk össze a ponthatárokat. Ahol nem indult az elmúlt három év mindegyikében a szak, azokat kihagytuk a jellemzésből (13. ábra). Megfigyelhető, hogy a felvételi ponthatárok növekvő tendenciát mutatnak, de átlagosan a ponthatár nem túl magas más képzésekhez viszonyítva.

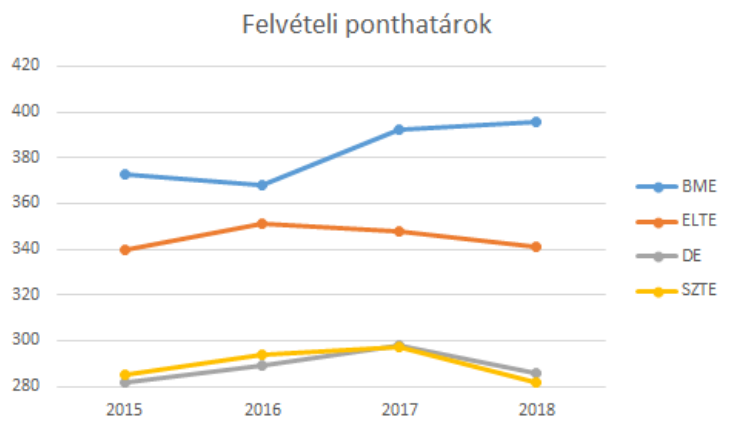

13. ábra. Ponthatárok változása 2015-2018 között.

Annak érdekében, hogy pontosabb képet kapjuk a felvételt nyert hallgatók pontjairól, bemutatjuk a hallgatók átlagpontszámát is.

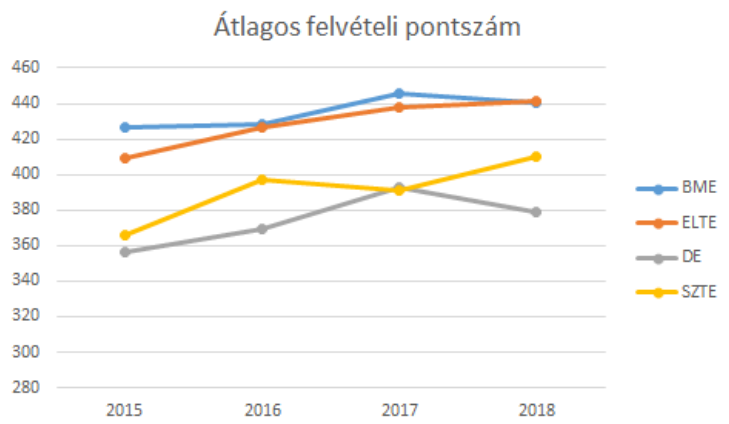

14. ábra. Átlagos pontszám egyetemenként.

Elemzésünk kiterjedt a matematika alapszakra felvett hallgatók összpontszámának egyetemek közötti megoszlására is (lásd a Függelékben). 


\section{Konklúzió, kitekintés}

Az egyetemi képzések előtanulmányi hálóinak jellemzésére és összehasonlíthatóságára mutattunk néhány módszert, és ezeket a magyarországi matematika alapképzéseken szemléltettük. Elemzésünk az irodalomban használatos gráfelméleti módszertanon alapszik, de újdonságként bemutattunk egy teljesítési adatokra alapuló valószínűségi modellt is. Ezen módszerek segítségével olyan kérdésekre kaphatunk választ, hogy egy adott tantervben melyik a legfontosabb, leghangsúlyosabb tantárgy, illetve az előtanulmányi háló topológiája hogyan hat a képzés várható teljesítési idejére. Továbbá ismertettünk néhány felvételi statisztikai adatot az elmúlt néhány évre vonatkozóan: többek között a matematika alapszakokra felvett hallgatók létszámának és felvételi pontszámainak alakulását.

Új módszereket mutattunk az egyetemi képzések előtanulmányi hálóinak jellemzésére, illetve az egyes tantárgyaknak a képzés várható végzési idejére vonatkozó hatását illetően. Elemzésünk újdonsága, hogy nemcsak az előtanulmányi háló struktúráját veszi figyelembe, hanem a tantárgyak teljesítési valószínüségeit is. A módszertant hazai matematika alapszakok mintatantervének összehasonlításával szemléltettük. Fontos megemlíteni, hogy valós tantárgyteljesítési adatok hiányában a modellünk eredményei csak nagyon korlátozottan értelmezhetőek. Az ismertetett módszerek azonban könnyen alkalmazhatóak valós teljesítési adatok ismeretében, mint ahogyan azt megtettük a BME esetében [7].

Elemzéseink során a könnyebb kezelhetőség érdekében számos egyszerüsítő feltétellel éltünk. Ezen feltételek elhagyása, azaz a modell finomítása pontosabb következtetések levonását teszi lehetővé. A továbbiakban célunk a különböző tantárgyak teljesítését nem egymástól független eseményeknek tekinteni, és az ehhez kapcsolódó feltételes valószínüségeket valós teljesítési adatokon feltérképezni. A reprezentatív hallgató feltevésünket finomítani szeretnénk a jövőben, beépítve a modellbe, hogy a valóságban a hallgatók szorgalma és képességei között nagy különbségek vannak. A feltételek elhagyásával azonban egy bonyolultabb, összetettebb modellt kapunk, ami a könnyü értelmezhetőség rovására mehet. Célunk, hogy a meglévő módszert hatékonyabbá és pontosabbá tegyük.

\section{Köszönetnyilvánítás}

A kutatás részben az EFOP-3.4.4-16. pályázat keretében valósult meg. Montolay Roland kutatása az Innovációs és Technológiai Minisztérium ÚNKP-19-3 kódszámú Új Nemzeti Kiválóság programjának támogatásával készült. Köszönettel tartozunk Lángné Lázi Mártának és Csabay Bálintnak a cikk elkészülte során nyújtott támogatásukért és hasznos tanácsaikért. 


\section{Hivatkozások}

[1] Akbaş, M. I., Basavaraj, P. and Georgiopoulos, M.: Curriculum GPS: an adaptive curriculum generation and planning system, Interservice/Industry Training, Simulation, and Education Conference (I/ITSEC), (2015).

[2] Aldrich, P. R.: The curriculum prerequisite network: Modeling the curriculum as a complex system, Biochemistry and Molecular Biology Education, Vol. 43 No. 3 pp. 168-180 (2015). DOI: 10.1002/bmb.20861

[3] Auvinen, T., PaAvola, J. and Hartikainen, J.: STOPS: a graph-based study planning and curriculum development tool, Proceedings of the 14th Koli Calling International Conference on Computing Education Research. ACM, pp. 25-34 (2014). DOI: $10.1145 / 2674683.2674689$

[4] Baker, R. S. And Inventado, P. S.: Educational data mining and learning analytics, Learning analytics, Springer New York, pp. 61-75 (2014). DOI: 10.1007/978-1-4614-3305$7 \_4$

[5] Balázs M. And Tóth B.: Valószinüségszámítás 1. jegyzet matematikusoknak és fizikusok$n a k,(2011)$.

[6] Barthelemy, M.: Betweenness centrality in large complex networks, The European physical journal B, Vol. 38 No. 2, pp. 163-168 (2004). DOI: 10.1140/epjb/e2004-00111-4

[7] Bergmann J. and Szekrényes D. L.: A probabilistic approach to the analysis of curriculum prerequisite networks, TDK, BME, (2017).

[8] Bonacich, P.: Some unique properties of eigenvector centrality, Social networks, Vol. 29 No. 4, pp. 555-564 (2007). DOI: 10.1016/j.socnet.2007.04.002

[9] Demcsákné Ódor Zs. And Huszárik P.: A felvételi eredmények és a tanulmányi elörehaladás összefüggései, Neptun-konferencia, (2017).

[10] EisenberG, B.: On the expectation of the maximum of IID geometric random variables, Statistics \& Probability Letters, Vol. 78 No. 2, pp. 135-143 (2008). DOI: 10.1016/j.spl.2007.05.011

[11] Fokozatváltás a felsőoktatásban középtávú szakpolitikai stratégia (1785/2016. (XII. 16.) Korm. határozat), (2016).

[12] HámoRi Á.: A 2017. évi keresztféléves eljárásban jelentkezők bejutási eredményessége regionális összevetésben, Feksőoktatási elemzési jelentések, Oktatási Hivatal, Felsőoktatási Elemzési Főosztály, (2017).

[13] Horváth D. M., Molontay R. And Szabó M.: Visualizing student flows to track retention and graduation rates, Proceedings of the 22nd International Conference on Information Visualisation, IEEE, pp. 338-343 (2018). DOI: 10.1109/iV.2018.00064

[14] JANSEN, E.: The influence of the curriculum organization on study progress in higher education. Higher education, Vol. 47 No. 4, pp. 411-435 (2004). DOI: 10.1023/B:HIGH.0000020868.39084.21

[15] Kabicher, S. And Motschnig-Pitrik, R.: Coordinating curriculum implementation using Wiki-supported graph visualization, Advanced Learning Technologies, (2009), ICALT (2009), Ninth IEEE International Conference on IEEE, pp. 742-743 (2009). DOI: 10.1109/ICALT.2009.54

[16] Katona Gy., Recski A. And Szabó Cs.: A számítástudomány alapjai, 2. kiadás, Typotex, (2007). 
[17] Lightfoot, J. M.: A Graph-Theoretic Approach to Improved Curriculum Structure and Assessment Placement, Communications of the IIMA, Vol. 10 No. 2, p. 5 (2010).

[18] Nagy M. and Molontay R.: Predicting Dropout in Higher Education based on Secondary School Performance, Proceedings of 22nd IEEE International Conference on Intelligent Engineering Systems, IEEE, pp. 389-394 (2018). DOI: 10.1109/INES.2018.8523888

[19] Saltzman, R. M. And Roeder, T. M.: Simulating student flow through a college of business for policy and structural change analysis. Journal of the Operational Research Society, Vol. 63 No. 4, pp. 511-523 (2012). DOI: 10.1057/jors.2011.59

[20] Slim, A., Kozlic, J., Heileman, G. L. and Abdallah, C. T. : Employing Markov Networks on Curriculum Graphs to Predict Student Performance, 13th International Conference on Machine Learning and Applications, (2014). DOI: 10.1109/ICMLA.2014.74

[21] Slim, A., Kozlick, J., Heileman, G. L., Wigdahl, J. and Avdallah, C. T.: Network Analysis of University Courses, International Worldwide Web Conference Committee, (2014). DOI: $10.1145 / 2567948.2579360$

[22] Slim, A., Kozlic, J., Heileman, G. L. and Abdallah, C. T.: The complexity of university curricula according to course cruciality, Complex, Intelligent and Software Intensive Systems (CISIS), Eighth International Conference, pp. 242-248 (2014). DOI: 10.1109/CISIS.2014.34

[23] Plotnicki, W. J. And Garfinkel, R. S.: Scheduling academic courses to maximize student flow: A simulation approach. Socio-Economic Planning Sciences, Vol. 20 No. 4, pp. 193-199 (1986). DOI: 10.1016/0038-0121(86)90010-8

[24] Rahim, R., Ibrahim, H., Kasim, M. M. and Adnan, F. A.: Projection model of postgraduate student flow. Appl. Math, Vol. 7 No. 2L, pp. 383-387 (2013). DOI: 10.12785/amis/072L01

[25] Van Der Hulst, M. And Jansen, E.: Effects of curriculum organisation on study progress in engineering studies. Higher Education, Vol. 43 No. 4, pp. 489-506 (2002). DOI: 10.1023/A:1015207706917

[26] Weber, A. C.: Simulating the Flow of Students Through Cal Poly's Undergraduate Industrial Engineering Program for Policy Analysis, (2013).

[27] Wigdahl, J.: Assessment Of Curriculum Graphs With Respect To Student Flow And Graduation Rates, Albuquerque, New Mexico: The University of New Mexico, Thesis, (2013).

[28] Wigdahl, J., Heileman, G. L., Slim, A. and Abdallah, C. T.: Curricular efficiency: What role does it play in student success?, Proceedings of the 121st ASEE Annual Conference and Exposition, IEEE, (2014). 


\section{A. FÜGGELÉK: Üvegnyakak és késleltetési tényezők}

A táblázatból kiolvasható, mely tantárgyak töltenek be üvegnyak szerepet az egyes képzések előtanulmányi hálóiban. Korábbi jelöléseinkkel élve (2.2), $a=2$ és $b=5$ paraméterekkel számoltunk.

\begin{tabular}{l}
\hline BME: \\
\hline Kalkulus 2 \\
Bevezetés az algebrába 2 \\
Algebra 1 \\
Valószínüségszámítás 1 \\
Informatika 2 \\
Topológia és differenciálható sokaságok \\
\hline \hline ELTE: \\
\hline Analízis 2 \\
Algebra 1 \\
Algebra 2 \\
Analízis 3 \\
Bev. a diff.geometriába \\
Számítástudomány \\
\hline \hline PTE: \\
\hline Bevezetés az algebrába és a számelméletbe 2. ea. \\
Bevezetés az analízisbe 2. ea. \\
\hline \hline DE: \\
\hline Lineáris algebra 1 \\
Diff. és integrálszámítás \\
Többvált. függv. diff- és intszám. \\
\hline \hline EKE: \\
\hline Analízis 2 \\
Bevezetés az algebrába és a számelméletbe \\
Lineáris algebra 1 \\
Analízis 3 \\
Geometria 2 \\
A matematika története \\
\hline
\end{tabular}

8. táblázat. Üvegnyakak. 
A késleltetési tényezők kiszámításánál feltételeztük, hogy minden tantárgy indul minden félévben, továbbá azt is, hogy az adott kurzus leszármazottjai első próbálkozásra sikerülnek. Eredményeinket a 9. táblázat mutatja.

\begin{tabular}{lr}
\hline BME kurzusai: & Késleltetési tényező \\
\hline Pénzügy & 1,00 \\
Mikroökonómia+Makroökonómia & 0,50 \\
Analízis 1 & 0,50 \\
Matematikai modellalkotás szeminárium & 0,50 \\
Analízis 2 & 0,50 \\
Differenciálgeometria 1 & 0,50 \\
Mértékelmélet & 0,50 \\
Algebra 2 & 0,50 \\
Topológia és differenciálható sokaságok & 0,50 \\
\hline ELTE kurzusai: & Késleltetési tényező \\
\hline Analízis 1 & 1,00 \\
Analízis 2 & 1,00 \\
Algebra 1 & 1,00 \\
Algebra 2 & 1,00 \\
Számelmélet 1 & 1,00 \\
Analízis 3 & 1,00 \\
Analízis 4 & 1,00 \\
Valószínűségszámítás 2 & 1,00 \\
Matematikai statisztika & 1,00 \\
Funkcionálanalízis 1 & 1,00 \\
Függvénysorok & 1,00 \\
Számítástudomány & 1,00 \\
Bev. a diff.geometriába & 0,50 \\
Valószínúségszámítás 1 & 0,50 \\
Differenciálegyenletek & 0,50 \\
Komplex függvénytan & 0,50 \\
Numerikus analízis & 0,50 \\
\hline DE kurzusai: & 1,00 \\
\hline Halmazok és függvények & 1,00 \\
Bevezetés az analízisbe & 1,00 \\
Diff. és integrálszámítás & 1,00 \\
Mérték- és integrálelmélet & 1,00 \\
Valószínűségszámítás & 1,00 \\
Statisztika & 1,00 \\
Elemi topológia & 0,50 \\
Többvált. függv. diff- és intszám. & 0,50 \\
Bev. a köz. diff.egyenletek elm. & 0,50 \\
Differenciálgeometria & 0,50 \\
Komplex függvénytan & \\
Fej. az elemi számelméletből &
\end{tabular}


Minőségbiztosítási ismeretek

0,50

PTE kurzusai

Késleltetési tényezö

Komputeralgebra

1,00

Multiplikatív számelmélet ea

1,00

Bev. az algebrába és a számelméletbe 1. ea.

0,50

Bev. az algebrába és a számelméletbe 2 . ea.

0,50

Bevezetés az analízisbe 1. ea.

0,50

Bevezetés az analízisbe 2 . ea.

0,50

Algebra és számelmélet 1 . ea.

0,50

Algebra és számelmélet 2. ea.

0,50

Analízis 1. ea.

0,50

Analízis 2. ea.

0,50

A matematika alapjai

0,50

Valószínűségszámítás és mat. statisztika 1. ea.

0,50

Valószínűségszámítás és mat. statisztika 2. ea.

0,50

Operációkutatás ea.

0,50

Számítástudományi alapismeretek

0,50

Komplex függvénytan elemei alkalmazásokkal ea.

0,50

Csoportelmélet ea.

0,50

\begin{tabular}{lr}
\hline EKE kurzusai: & Késleltetési tényező \\
\hline Lineáris algebra 2 & 1,00 \\
Komputeralgebrai rendszerek & 1,00 \\
Operációkutatás & 1,00 \\
Komplex függvénytan & 1,00 \\
Matematikai praktikum 2 & 0,50 \\
Analízis 1 & 0,50 \\
Analízis 2 & 0,50 \\
Geometria 1 & 0,50 \\
Lineáris algebra 1 & 0,50 \\
Analízis 3 & 0,50 \\
Geometria 2 & 0,50 \\
Bevezetés a valószínúségszámításba & 0,50 \\
Geometria 3 & 0,50 \\
Matematikai statisztika & 0,50 \\
Projektív geometria & 0,50 \\
A matematika története & 0,50 \\
\hline
\end{tabular}

9. táblázat. Késleltetési tényezők.

A nemnulla kölcsönös központiságú tárgyak a 10. táblázatban olvashatók.

\begin{tabular}{lr}
\hline BME kurzusai: & Kölcsönös központiság \\
\hline Kalkulus 2 & 8,50 \\
Bevezetés az algebrába 2 & 6,00
\end{tabular}


Analízis 1

Algebra 1

Geometria

Valószínűségszámítás 1

Informatika 2

Analízis 2

Differenciálgeometria 1 3,50

ELTE kurzusai: Kölcsönös központiság

Analízis 2

Algebra 2

22,50

Geometria 1

1,50

Véges matematika 2

2,00

Analízis 3

18,00

Analízis 4

Algebra 3

3,00

Geometria 2

3,00

Valószínűségszámítás 1

6,00

Valószínüségszámítás 2

9,00

Funkcionálanalízis 1

2,00

Operációkutatás 1

2,00

PTE kurzusai:

Kölcsönös központiság

Bevezetés az algebrába és a számelméletbe 2. ea.

Bevezetés az analízisbe 2. ea.

Algebra és számelmélet 1. ea.

Analízis 1. ea.

4,00

Analízis 2. ea.

Geometria 1. ea.

Geometria 2. ea.

Valószínűségszámítás és matematikai statisztika 1. ea.

Programozás 1. gyakorlat

Numerikus analízis 1 . ea.

\begin{tabular}{lr}
\hline DE kurzusai: & Kölcsönös központiság \\
\hline Lineáris algebra 1 & 5,00 \\
Bevezetés az analízisbe & 9,00 \\
Bev. az alg. és számelméletbe & 5,00 \\
Számelmélet 1 & 4,00 \\
Diff. és integrálszámítás & 16,00 \\
Geometria 1 & 3,00 \\
Geometria 2 & 3,00 \\
Lineáris algebra 2 & 3,00 \\
Algebra & 2,00 \\
Többvált. függv. diff- és intszám. & 9,00 \\
Mérték- és integrálelmélet & 6,00 \\
Valószínúségszámítás & 4,00 \\
\hline
\end{tabular}




\begin{tabular}{lr}
\hline EKE kurzusai: & Kölcsönös központiság \\
\hline Analízis 2 & 9,00 \\
Bevezetés az algebrába és a számelméletbe & 6,00 \\
Geometria 1 & 6,00 \\
Analízis 3 & 17,50 \\
Geometria 2 & 11,00 \\
Számelmélet 1 & 4,00 \\
Bevezetés a valószínűségszámításba & 5,00 \\
Lineáris algebra 2 & 0,50 \\
\hline
\end{tabular}

10. táblázat. Kölcsönös központiságok. 


\section{B. FÜGGELÉK: Hazai matematika alapképzések felépítése}

Ebben a fejezetben a képzés felépítése, az induló specializációk és sávok szerint hasonlítjuk össze a hazai matematika alapszakokat az egyetemek honlapján található információk alapján.

\section{B.1. ELTE}

Hazánk egyik legnagyobb egyetemén a hallgatók három specializáció közül választhatnak a matematika BSc képzésen. Ezek:

- matematika,

- alkalmazott matematika,

- matematikai elemző.

A hallgatók a második félévig közös képzésben vesznek részt, majd a harmadik szemeszterben választanak specializációt. Az idejáró diákok tantárgyaikat, saját érdeklődési körük szerint, különböző szinteken sajátíthatják el. Választhatnak a normál, intenzív és haladó szintek között. A haladó szint csak a véges matematika témakörébe tartozó kurzusok esetén indul. Ezen a szinten csak az anyag tárgyalásának sebességében és mélységében különböznek, de adminisztratív szempontból ekvivalensek. Ezek a tantárgyváltozatok szabadon választhatók és szabadon átjárhatók.

A képzés során 180 kreditet kell teljesíteni, melyből 54 kreditet tesz ki az első évben a közös képzés. Részletesebben a tantárgycsoportok megoszlását a következő táblázat mutatja be:

\begin{tabular}{r|r}
\hline & Kredit \\
\hline Kötelező & 149 \\
Kötelezően választható & 12 \\
Szabadon választható tantárgy & 9 \\
Szakdolgozat & 10 \\
\hline Öszesen & 180 \\
\hline
\end{tabular}

\section{B.2. BME}

2015-től új lehetőségeket kínál BME a specializációkat illetően. Az idejárók a következő két specializáció és további négy sáv közül választhatnak:

- elméleti matematika,

- alkalmazott matematika, adattudomány, 
mérnök matematika,

operációkutatás,

sztochasztika.

A specializáció kurzusai az 5. félévtől kezdődnek.

Az egyes tantárgycsoportok krediteit ismerteti az alábbi táblázat.

\begin{tabular}{r|r}
\hline & Kredit \\
\hline Alapozó ismeretek & 19 \\
Szakmai törzsanyag & 21 \\
Differenciált szakmai ismeretek & 70 \\
Specializáció tantárgyak & 29 \\
Kötelezően választható tantárgyak & 22 \\
Szabadon választható tantárgyak & 9 \\
Szakdolgozat & 10 \\
\hline Öszesen & 180 \\
\hline
\end{tabular}

\section{B.3. DE}

Debrecenben két specializáció van:

- matematika,

- alkalmazott matematika.

A képzés tantárgycsoportonkénki kreditmegoszlása a következő:

\begin{tabular}{r|r}
\hline & Kredit \\
\hline Dörzsanyag & 50 \\
Differenciált szakmai anyag & 47 \\
Specializáció kötelező szakmai anyag & 38 \\
Specializáció választható tantárgy & 13 \\
Környezettani, Európai Uniós, minőségbiztosítási ismeretek & 5 \\
Természettudományi alapismeretek & 8 \\
Szabadon választható tantárgy & 9 \\
Szakdolgozat & 10 \\
\hline Öszesen & 180 \\
\hline
\end{tabular}

\section{B.4. PTE}

Pécsett két specializáció van, az egyik a tanári szakirány, a másik az úgynevezett szakirány nélküli képzés. A szakirányok választására az első év után van lehetőség, habár 120 kredit kötelező mindkét specializáció számára. A kreditek tantárgycsoportonkénti megoszlása a követekező: 


\begin{tabular}{r|r}
\hline & Kredit \\
\hline Alapozó modul & 22 \\
Szakmai törzsmodul & 68 \\
Kötelezöen választható tantárgyak modulja & 10 \\
Szabadon választott tantárgyak modulja & 10 \\
Szakdolgozat & 10 \\
Szakirány nélküli tantárgyak modulja & 60 \\
\hline Öszesen & 180 \\
\hline
\end{tabular}

\section{B.5. EKE}

Egerben nincs külön szakirányválasztás. A többi képzéshez hasonlóan itt is 180 kreditet kell teljesíteni a diploma megszerzéséhez, melyből 10 kredit a szakdolgozatírásért jár. A kreditek megoszlása a következőképpen néz ki:

\begin{tabular}{r|r}
\hline & Kredit \\
\hline Értelmiségi modul & 11 \\
Természettudományi ismeretek modul & 4 \\
Alapozó szakmai modul & 22 \\
Szakmai törzsmodul & 32 \\
Differenciált szakmai ismeretek & 81 \\
Választható szakmai tantárgyak modulja & 11 \\
Szabadon választott tantárgyak modulja & 9 \\
Szakdolgozat & 10 \\
\hline Öszesen & 180 \\
\hline
\end{tabular}

Az első négy modul más szakokkal közös, de a további modulok a matematikus specializációhoz tartozó ismeretek.

\section{B.6. SZTE}

A Szegedi Tudományegyetem matematika alapszakának előtanulmányi hálója nyilvánosan nem elérhető, ezért kimaradt korábbi elemzésünkből, ám néhány adatot sikerült találni a struktúrájáról. A következő ösvények közül lehet választani:

- alkalmazott matematikus specializáció,

- gazdasági specializáció,

- informatikai specializáció,

- matematikus specializáció,

- specializáció nélküli. 
Az egyes tantárgycsoportokhoz rendelt kreditszámokat a következő táblázat mutatja. Szegeden egyik tantárgycsoporthoz sincs pontos kreditszám meghatározva, ezek az értékek minimum elvégzendő krediteket jelölnek. Ebből adódóan viszonylag nagy szabadságot kapnak a hallgatók a kurzusválasztást illetően, hiszen 51 kreditet szabadon oszthatnak el a képzés alatt.

\begin{tabular}{r|r}
\hline & Kredit (min.) \\
\hline Alapozó ismeretek & 19 \\
Szakmai törzsanyag & 24 \\
További kötelező matematika tantárgyak & 39 \\
Kötelezően választható tantárgyak & 30 \\
Egyéb tantárgyak & 51 \\
Szakmai gyakorlat & 3 \\
Szakdolgozat & 14 \\
\hline Öszesen & 180 \\
\hline
\end{tabular}

A hallgatók a BME és a SZTE képzésén választhatnak a legtöbbféle specializáció közül. Az ELTE képzésén a diákok szabadon dönthetnek, hogy a kurzust milyen szinten szeretnék hallgatni. A legnagyobb szabadságot adó képzés a BME képzése, ahol a hallgatóknak a legkevesebb kötelező kreditet kell elvégezni, a hiányzó krediteket a kötelezően választható tantárgyakból pótolják.

Különösen érdekes lenne a matematika alapszakok felépítésének és mintatantervének vizsálata nemzetközi kitekintésben, de ezen elemzés kimutatna jelen tanulmányunk keretei közül. 


\section{FÜGGELÉK: Felvételi statisztikák}

A következő táblázatokban évenkénti bontásban közöljük a hazai matematika alapszakok felvételi statisztikáit 2015-től 2018-ig.

\begin{tabular}{c|rrrrrrr}
\hline & BME & ELTE & PTE & DE & EKE & SZTE & NYME \\
\hline $\begin{array}{c}\text { Felvett hallgatók létszáma } \\
\text { önköltséges képzésen }\end{array}$ & 2 & 6 & 0 & 1 & 0 & 3 & 1 \\
$\begin{array}{c}\text { Felvett hallgatók létszáma } \\
\text { állami ösztöndíjas képzésen }\end{array}$ & 51 & 132 & 9 & 26 & 0 & 39 & 4 \\
$\begin{array}{c}\text { Felvett hallgatók létszáma } \\
\text { összesen }\end{array}$ & 53 & 138 & 9 & 27 & 0 & 42 & 5 \\
$\begin{array}{c}\text { Felvételi ponthatár (ANA) } \\
\text { Átlagos felvételi pontszám }\end{array}$ & 373 & 340 & 324 & 282 & & 285 & \\
Minimális létszám & 426,84 & 409,4 & 377,22 & 356,78 & & 365,76 & 346,2 \\
Maximális létszám & 20 & 15 & 5 & 10 & 5 & 10 & 5 \\
\hline
\end{tabular}

11. táblázat. 2015-ben nappali matematika alapképzésre felvettek adatai.

\begin{tabular}{c|rrrrrrr}
\hline & BME & ELTE & PTE & DE & EKE & SZTE & NYME \\
\hline $\begin{array}{c}\text { Felvett hallgatók létszáma } \\
\text { önköltséges képzésen }\end{array}$ & 0 & 9 & 0 & 2 & 0 & 0 & 0 \\
$\begin{array}{c}\text { Felvett hallgatók létszáma } \\
\text { állami ösztöndíjas képzésen }\end{array}$ & 45 & 109 & 0 & 11 & 0 & 30 & 0 \\
$\begin{array}{c}\text { Felvett hallgatók létszáma } \\
\text { összesen }\end{array}$ & 45 & 118 & 0 & 13 & 0 & 30 & 0 \\
Felvételi ponthatár (ANA) & 368 & 351 & n. i. & 289 & n. i. & 294 & n. i. \\
Átlagos felvételi pontszám & 428,37 & 426,88 & 0 & 369,54 & 0 & 396,83 & 0 \\
Minimális létszám & 20 & 15 & 5 & 5 & 5 & 5 & 5 \\
Maximális létszám & 70 & 140 & 20 & 50 & 20 & 70 & 15 \\
\hline
\end{tabular}

12. táblázat. 2016-ban nappali matematika alapképzésre felvettek adatai.

Megjegyezzük, hogy Szegeden és Egerben levelező tagozat indult. 


\begin{tabular}{c|rrrrrr}
\hline & BME & ELTE & PTE & DE & EKE & SZTE \\
\hline $\begin{array}{c}\text { Felvett hallgatók létszáma } \\
\text { önköltséges képzésen }\end{array}$ & 3 & 6 & 0 & 2 & 0 & 1 \\
$\begin{array}{c}\text { Felvett hallgatók létszáma } \\
\text { állami ösztöndíjas képzésen }\end{array}$ & 43 & 111 & 0 & 12 & 0 & 26 \\
$\begin{array}{c}\text { Felvett hallgatók létszáma } \\
\text { összesen }\end{array}$ & 46 & 117 & 0 & 14 & 0 & 27 \\
$\begin{array}{c}\text { Felvételi ponthatár (ANA) } \\
\text { Átlagos felvételi pontszám }\end{array}$ & 392 & 348 & n. i. & 298 & n. i. & 297 \\
Minimális létszám & 445,49 & 437,95 & 0 & 392,71 & & 391,33 \\
Maximális létszám & 20 & 15 & 5 & 10 & 5 & 5 \\
\hline
\end{tabular}

13. táblázat. 2017-ben nappali matematika alapképzésre felvettek adatai.

Megjegyezzük, hogy 2017-től a BME angol nyelven is elindítja az alapképzést, de angol nyelvü képzés nem képzi jelen vizsgálódásunk tárgyát.

Láthatjuk, hogy az ELTE rendelkezik a legnagyobb létszámú matematika képzéssel. Vidéken a Szegedi Tudományegyetem a legjelentősebb.

\begin{tabular}{c|rrrrrr}
\hline & BME & ELTE & PTE & DE & EKE & SZTE \\
\hline $\begin{array}{c}\text { Felvett hallgatók létszáma } \\
\text { önköltséges képzésen }\end{array}$ & 0 & 5 & 0 & 2 & 0 & 0 \\
$\begin{array}{c}\text { Felvett hallgatók létszáma } \\
\text { állami ösztöndíjas képzésen }\end{array}$ & 41 & 127 & 5 & 15 & 0 & 15 \\
$\begin{array}{c}\text { Felvett hallgatók létszáma } \\
\text { összesen }\end{array}$ & 41 & 132 & 5 & 17 & 6 & 15 \\
$\begin{array}{c}\text { Felvételi ponthatár (ANA) } \\
\text { Átlagos felvételi pontszám }\end{array}$ & 396 & 341 & 282 & 286 & 329 & 282 \\
Minimális létszám & 440,02 & 440,94 & 358,00 & 379,76 & n.i. & 410,33 \\
Maximális létszám & 20 & 15 & 4 & 5 & 5 & 5 \\
\hline
\end{tabular}

14. táblázat. 2018-ban nappali matematika alapképzésre felvettek adatai.

A 15. ábrán azt szemléltetjük, hogy hogyan oszlanak meg a diákok által hozott összpontszámok az egyes egyetemek között. Egy egyetemre felvett hallgatók létszámát megszoroztuk a hozott átlagponttal, és ennek arányát néztük az összes 
felvetthez képest. Formálisan,

$$
\text { (részesedési arány })_{i}=\frac{n_{i} \cdot \mu_{i}}{n \cdot \mu},
$$

ahol $n$ az összes felvett hallgató száma, $\mu$ az összes hallgató átlagpontszáma, $n_{i}$ az $i$ egyetemre felvett hallgatók száma, $\mu_{i}$ pedig ezen hallgatók átlagpontszáma.

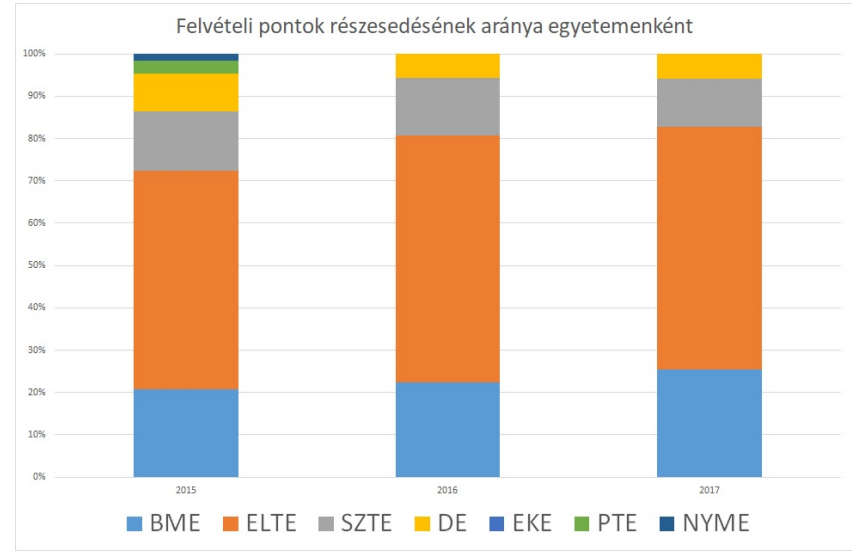

15. ábra. Felvételi pontszámok részesedése.

Ezen részesedési arány mutatja, hogy a matematika szakra felvett hallgatók összpontszáma hogyan oszlik el az egyes egyetemek között. Egy sáv növekedése magyarázható az adott egyetemre felvett hallgatók számának a növekedésével vagy a felvett hallgatók átlagpontszámának emelkedésével.

(Beérkezett: 2018. február 26.) 


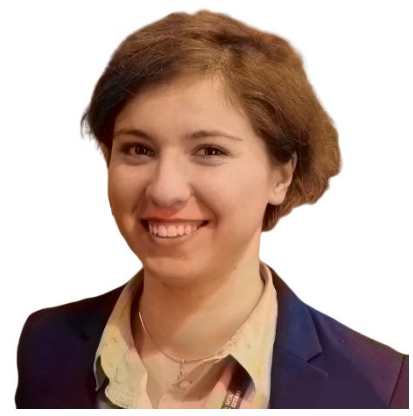

Bergmann Júlia 1992-ben született Szekszárdon. A 2011-ben tett érettségije után a Budapesti Müszaki és Gazdaságtudományi Egyetem hallgatója lett, ahol 2015-ben alapszakos, majd 2018-ban mesterszakos matematikus diplomát szerzett analízis specializációval. 2017-ben tantervi hálók elemzéséről szóló tudományos diákköri dolgozatával I. díjat ért el. Diplomaszerzés után az SZTAKI Mérnöki és Üzleti Intelligencia Kutatólaboratóriumában helyezkedett el adatelemzőként, ahol adatalapú ipari digitalizációs megoldások fejlesztésével és folyamatoptimalizálással foglalkozik, továbbá a Fraunhofer Társaság különböző intézeteivel együtt végez kutatómunkát.

BERGMANN JÚLIA

Természettudományi Kar

Budapesti Műszaki és Gazdaságtudományi Egyetem

H 1111 Budapest, Múegyetem rkp. 3-9.

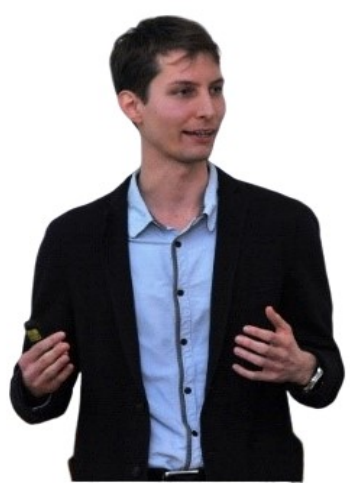

Molontay Roland 1991-ben született Budapesten. A Városmajori Gimnáziumban érettségizett, majd a Budapesti Müszaki és Gazdaságtudományi Egyetemen folytatta tanulmányait, ahol 2015-ben kitüntetéses alkalmazott matematikusi diplomát szerzett. Doktori tanulmányait a BME Matematika és Számítástudományi Doktori Iskolájában folytatta hálózatelméleti témában Simon Károly témavezetésével. 2016-ban az egyesült államokbeli Brown Egyetemen volt vendégdoktorandusz. 2012 óta oktat a Müegyetem Sztochasztika Tanszékén, 2019-től pedig az Aquincum Institute of Technologyban is. 20 tudományos közlemény szerzője, nemzetközi konferenciák rendszeres előadója. 2018-ban a BME Sztochasztika Tanszék magas színvonalú oktatói-kutatói munkájáért Innovációs Díjjal tüntette ki, 2019ben pedig a hallgatók javaslata alapján a BME TTK Kari Tanácsa a Kar Kiváló Oktatója kitüntetéssel jutalmazta, kiterjedt tehetséggondozó munkájáért a Pro Progressio Alapítvány Oktatói TDK Különdíjában részesült. Jelenleg az MTABME Szochasztika Kutatócsoport munkatársa, a HU-MATHS-IN Hálózat tagja, az Új Nemzeti Kiválósági Program ösztöndíjasa.

MOLONTAY ROLAND

Matematika Intézet, Sztochaszika Tanszék

Természettudományi Kar

Budapesti Műszaki és Gazdaságtudományi Egyetem

H 1111 Budapest, Müegyetem rkp. 3-9. 


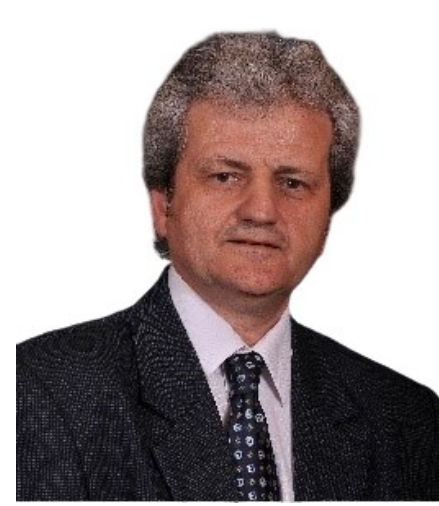

Szabó Mihály 1956-ban született, a Budapesti Műszaki Egyetem Vegyészmérnöki Karán diplomázott 1979-ben, majd 1987-ben általános kémiai technológia "szaktudományból" müszaki doktori címet szerzett. 1993-1997 között a Vegyészmérnöki Kar dékáni hivatalvezetője, majd irányításával hozták létre 2004-ben az egyetem Központi Tanulmányi Hivatalát, amit azóta is vezet. Részt vett a kreditrendszerű képzést kiszolgáló első tanulmányi rendszer kidolgozásában. 40 éve oktat a BME Vegyészmérnöki és Biomérnöki Karának Kémiai és Környezeti Folyamatmérnöki Tanszékén.

SZABÓ MIHÁLY

Központi Tanulmányi Hivatal

Budapesti Müszaki és Gazdaságtudományi Egyetem

H 1111 Budapest, Mủegyetem rkp. 3-9.

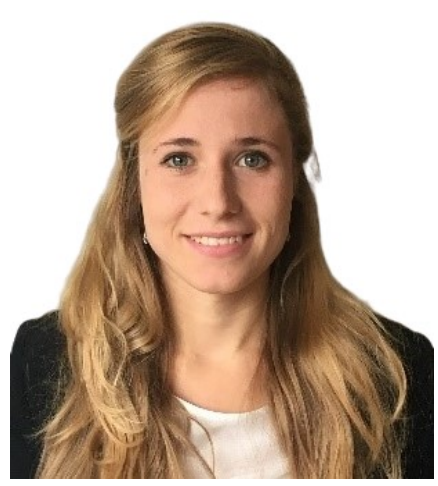

Szekrényes Dóra 1993-ban született Budapesten. 2013-ban érettségizett a Premontrei Szent Norbert Gimnáziumban, majd a Budapesti Müszaki és Gazdaságtudományi Egyetemen folytatta tanulmányait, ahol 2016-ban matematika alapszakos, 2018-ban pedig alkalmazott matematikus mesterszakos diplomát szerzett. 2017-ben tantervi hálók elemzéséről szóló tudományos diákköri dolgozatával I. díjat ért el. 2018 óta az okos város gyakorlati megvalósításait kutatja a CHAOS Architects gépi tanulási algoritmusok fejlesztőjeként.

SZEKRÉNYES DÓRA LAURA

Természettudományi Kar

Budapesti Műszaki és Gazdaságtudományi Egyetem

H 1111 Budapest, Müegyetem rkp. 3-9. 


\title{
ANALYZING THE CURRICULA AND PREREQUISITE NETWORKS OF HUNGARIAN MATHEMATICS BSC PROGRAMS
}

\author{
Júlia Bergmann, Roland Molontay, Mihály Szabó, Dóra laura Szekényes
}

In this paper, we present several methods for analyzing and comparing prerequisite networks of university programs, we evaluate these methods on the curricula of Mathematics BSc programs in Hungary. Also, a brief literature review on the analysis of prerequsite networks is given, and a new data based probabilistic model is presented. Using these methods one can easily answer various important questions, such as which course is the most crucial, or what effect the topology of a network has on the expected time of graduation. Furthermore, results of enrollment process from previous years are summarized regarding Hungarian mathematics BSc programs. 